\title{
Chemical Contaminants Associated with Palm Wine from Nigeria Are Potential Food Safety Hazards
}

\author{
Ogueri Nwaiwu $^{1, *}$ and Martin Itumoh ${ }^{2}$ \\ 1 Research Services, Alpha Altis, Sir Collin Campbell Building, University of Nottingham Innovation Park, \\ Triumph Road, Nottingham NG7 2TU, UK \\ 2 Department of Agribusiness and Management, Faculty of Agriculture, Federal University Ndufu Alike \\ Ikwo, Ebonyi 480101, Ebonyi State, Nigeria; martin.itumoh@funai.edu.ng \\ * Correspondence: ogueri.nwaiwu@alpha-altis.co.uk; Tel.: +44-785-317-9327
}

Academic Editor: Dimitrios Zabaras

Received: 30 November 2016; Accepted: 26 February 2017; Published: 3 March 2017

\begin{abstract}
Recent analysis of palm wine, a traditional drink fermented mainly by yeasts, revealed the presence of several chemicals that were not products of yeast fermentation. The chemicals included styrene, benzene, trimethyldioxolane, dichloromethane, methylene fluoride, dichloroethanol, benzylisoquinoline and tetraacetyl-D-xylonic nitrile. A review of the concentrations of these compounds in palm wine found that the benzene concentrations in all samples reviewed ranged from 56-343 ppm and were within permissible limits, whereas the styrene values (1505-5614 ppm) in all the palm wine samples evaluated were well over the recommended concentration that is immediately dangerous to life or health. Other chemical compounds evaluated varied according to location or sample source. The concentrations obtained are estimates only and a quantitative study needs to be carried out before the impact of these chemicals on health is evaluated. A search on The PubChem Project, the open chemical database, showed the description, properties and uses of these chemicals. Further searches carried out within other databases like PubMed, Scopus and Google Scholar, using each chemical's name as a search term, showed possible hazards and adverse health conditions caused by these chemicals, especially styrene, benzene and dichloromethane. The point at which the chemicals are introduced into the drink is still not clear and requires further investigation. The chemicals can be hazardous to humans and there is need to establish and maintain a system that can guarantee permissible levels in the drink. This can be carried out using concentrations of the chemicals that are already known to be immediately dangerous to life or health as a reference point.
\end{abstract}

Keywords: palm wine; chemicals; contaminant; styrene; benzene; food safety; hazard, plastic

\section{Introduction}

Palm wine is a traditional drink produced by different types of palm trees and is enjoyed by many people living in sub-Saharan Africa. Around the world, the beverage is popular and is known by different names. Increased microbiological studies of the product in the last five years has led to more information on the diversity of Saccharomyces cerevisiae strains prevalent in the product $[1,2]$ and discovery of new microorganisms from the drink [3]. The tapping of the drink from the palm tree provides a very important economic activity for people living outside of the cities, and the drink plays an important role in the socio-cultural activities of people in Nigeria, where, in the southeastern region, it is served in most traditional events. The drink is now beneficial to different groups of people in that some people in Nigeria who are cutting alcohol consumption resort to freshly tapped product which is sweet and without much alcohol.

The commercial production of the drink has increased and it is now canned. The drink is commonly produced in beer like bottles in Nigeria and a good number of retailers sell the product with reused 
table water plastic bottles with the cap loosely fitted to reduce foaming. The vast production and sale of the product is not regulated and this makes the drink predisposed to food safety hazards which could be biological, chemical, physical, allergenic, nutritional or biotechnology-related [4]. It has been reported that the drink can be contaminated at multiple steps in the production process and should be regulated for quality control to avoid health risks [5]. In addition, plant material treated with herbicides and pesticides can be present in the palm wine processing environment, and it is not uncommon to see producers that use leaves to cover containers containing the drink. Leaves, stem and bark can also get into the palm wine either when the incision is made to begin the tapping process or when the sap is flowing into a container. In some palm wine processing environments, insects could be a source of food safety hazards when they fly into bowls or containers containing the drink.

Food safety hazards [6] occur when food is exposed to hazardous agents and results in contamination of the food. It may occur through air, soil and water in the environment. Furthermore, in the food industry, there are various types of chemical hazards and they include mycotoxins, natural toxins, marine toxins, environmental contaminants, food additives, processing-induced chemicals, pesticides, agricultural products and veterinary drug residues [5]. Currently, there is no evidence that hazard analysis and critical control points (HACCP), a systematic preventive approach to food safety from biological, chemical, and physical hazards, are used during the production of palm wine among local processors. Many workers [7-9] have studied the microbial and biochemical constituents of the drink, especially compounds of microbial fermentation, and they are not currently regarded as hazards.

There are rarely any reports on the chemical contaminants of the product. The metal concentrations of 13 elements in the drink have been determined, and it was found that, from the estimated target hazard, no long life health concerns of metals are associated with the consumption of Raphia palm wine [10]. The chemical contaminants per se were not analyzed in that study. However, it was found that the individual and combined metal target hazard quotient values of Raphia palm wine were higher in other traditional alcoholic drinks. The lack of information on chemical contaminants of palm wine has created a paucity of information on the properties of non-ethanol and non-microbial components associated with the drink as well as other food safety hazards linked with unregulated processing of the beverage.

In a previous study [11], some chemical compounds were not identified as products of yeast fermentation in palm wine after a search on the yeast metabolome database (YMDB) was carried out [12], and it was suggested that the contaminants were artifacts from the environment. Irrespective of how the chemical contamination occurred, the presence of these substances in palm wine is not desirable. Therefore, the aim of this review was to focus on these chemical contaminants and highlight safety concerns that should be addressed for the health benefits of palm wine consumers. To this end, the properties, uses, toxicity, and health issues associated with palm wine chemical contaminants detected in the previous study were explored in more detail in order to raise more awareness on the possible hazards that could arise from consumption of the beverage.

\section{Methods}

The chemical contaminants found in palm wine (Figure 1) are listed in Table 1. In the absence of actual sources of these contaminants, the hypothetical sources are specified. An investigation [11] reported that palm wine obtained from trees of Elaeis sp. and Raphia sp. were purchased $(1.5 \mathrm{~L}$ pack size) from six different open markets in southeastern Nigeria. Using a wide range of analytical techniques, the microbial and chemical contents were determined. In particular, the use of gas chromatography-mass spectrometry (GC-MS) revealed that all the palm wine samples contained chemical compounds that are known carcinogens. There is a paucity of data on palm wine contaminants in literature. However, an earlier study [13] reported some of the compounds listed (Table 1) and it included styrene and dimethylbenzene. Another investigation reported [14] the presence of phenyl compounds among other volatiles. A search was conducted within The PubChem Project, the open 
chemical database [15], to establish the description and uses of candidate chemicals (Table 1). The main reason for including these chemicals in the search was because they are not associated with yeast fermentation of palm wine. The compound identifier and uses of these chemicals were captured.

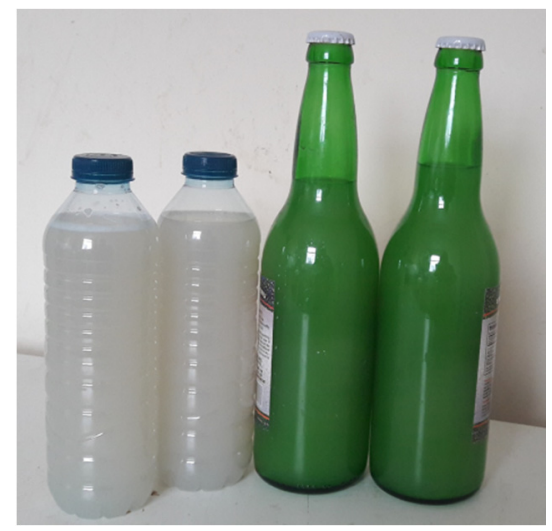

Figure 1. Representative samples of palm wine bottles sold in Nigeria. The samples in glass bottles (right) are now exported around the world. Samples in polyethylene terephthalate bottles (left) with polystyrene caps are normally found in small retail outlets.

Table 1. Estimated concentrations of chemical contaminants associated with palm wine samples.

\begin{tabular}{|c|c|c|c|c|c|c|c|c|c|c|c|}
\hline \multirow{2}{*}{ Compounds } & \multirow{2}{*}{$\begin{array}{l}\text { PubChem } \\
\text { CID }^{1}\end{array}$} & \multicolumn{7}{|c|}{ Estimated Concentrations ${ }^{2}$ in Palm Wine (ppm) } & \multirow{2}{*}{$\begin{array}{l}\text { IDLH }^{3} \\
(\mathrm{ppm})\end{array}$} & \multirow{2}{*}{ Uses } & \multirow{2}{*}{$\begin{array}{l}\text { Possible } \\
\text { Sources }\end{array}$} \\
\hline & & S1 & S2 & S3 & S4 & S5 & S6 & S7 & & & \\
\hline 1. Styrene & 7501 & 4495 & 4299 & 3132 & 1938 & 1867 & 1505 & 5614 & 700 & Plastics & Plastic container \\
\hline 3. Trimethyldioxolane & 12586 & 3281 & 1533 & 789 & 3560 & 462 & 2298 & 3581 & $500^{4}$ & Solvent & Derivative \\
\hline 6. Dichloroethanol & 11718 & 693 & 118 & 134 & 158 & 70 & 390 & 125 & $3000^{6}$ & Solvent & Environment \\
\hline 7. Dimethylhydrazine & 5976 & 926 & 4889 & 9162 & 7238 & 352 & 766 & 540 & 50 & Pesticides & Environment \\
\hline 8. Dimethylhydrazine & 16680696 & 73 & 138 & 210 & 169 & 127 & 53 & 116 & $66.1^{7}$ & Pharmacy & Leaves or tissue \\
\hline 9. Tetraacetyl-D-xylonic & 541568 & 87 & 68 & 132 & 96 & 118 & 88 & 152 & $250^{8}$ & Plant part & $\begin{array}{l}\text { Plant compound } \\
\text { nitrile }\end{array}$ \\
\hline
\end{tabular}

${ }^{1} \mathrm{CID}=$ compound identifier; Information sourced from PubChem open chemistry database [15]. ${ }^{2}$ Concentrations estimated in palm wine from Nwaiwu et al. study [11]. ${ }^{3} \mathrm{IDLH}=$ Immediately dangerous to life or health; $\mathrm{S}=$ sample. ${ }^{4}$ IDLH for Dioxane. ${ }^{5}$ IDLH for Fluorine. ${ }^{6}$ IDLH for Dichloroethane. ${ }^{7}$ IDLH for Quinone. ${ }^{8}$ IDLH for Phenol.

To verify safe levels, another search was performed on the revised list of immediately dangerous to life or health concentrations (IDLH) of chemicals held by the Center for Diseases Control and Prevention, United States of America [16]. Where the exact compound of interest was absent on the list, a closely related compound was highlighted. In the previous work [11], the chemical abundance was determined by comparing GC-MS peak areas across samples. In this review, we used the peak areas within samples to estimate the percentage concentration before converting to parts per million (Table 1) and then compared values obtained with IDLH limits. Further searches were carried out on other databases like PubMed, Scopus and Google Scholar using each chemical's name as a search term. The search strategy employed focused mainly on articles from the last 10 years and only articles that had information on how these chemicals affect public health were selected. The capacity to cause harm by the chemicals of interest was noted. Possible hazards from polyethylene terephthalate (PET), a common retailing container, were highlighted. 


\section{Styrene}

According to the United States Department of Energy [17], styrene monomer is a colorless oily liquid, large-volume chemical used in making polyesters, resins, and chemical intermediates with a global market value of approximately $\$ 32.5$ billion. Most PET bottles used for retailing palm wine have a polystyrene cap, which is a safety concern if styrene migrates to the drink. An in vitro genotoxicity investigation to evaluate the genotoxicity of styrene oligomers extracted from polystyrene intended for use in contact with food has been conducted [18], and it was concluded that the risk of the genotoxicity of styrene oligomers migrating from polystyrene food packaging into food is likely very low.

\section{Styrene Exposure}

In all samples, the estimated styrene concentration was over the concentration immediately dangerous to life or health (Table 1). Although styrene exposure will occur mainly to those that are involved in the manufacturing of plastics and composites, the detection of high concentrations of the monomer in palm wine suggests that there is some form of exposure to palm wine consumers. It also indicates that not all containers used for the drink are food grade. Adverse properties of styrene exposure have been reported and styrene has been linked to eosinophilic bronchitis [19] and transient bilateral vestibular dysfunction [20]. It has also been reported that styrene has an effect on hearing loss [21,22] and may affect neurological behavior [23,24]. The effect of occupational exposure to styrene on frequencies of chromosomal aberrations and binucleated cells with micronuclei and on single-strand break levels in peripheral blood lymphocytes has also been studied in styrene-exposed lamination workers [25]. It was found that positive correlation between exposure parameters and DNA repair rates suggests that particular DNA repair pathways may be affected by styrene exposure.

\section{Benzene}

\subsection{Benzene as a Carcinogen}

Even though all samples evaluated were within permissible limits (Table 1), the exact route of entry of benzene into palm wine needs to be established due to the carcinogenic nature of the drink. The compound is a known human carcinogen for all routes of exposure and is a widely used chemical formed from both natural processes and human activities [26]. It is also believed to rank in the top 20 chemicals for production volume. Furthermore, industries use benzene to make other chemicals that are used to make plastics, resins, and nylon and other synthetic fibers. Benzene is found in the air from emissions from burning coal and oil, gasoline service stations, cigarette smoke and motor vehicle exhaust. Inhalation exposure of humans to benzene may cause drowsiness, dizziness, headaches, as well as eye, skin, respiratory tract irritation, and unconsciousness [15]. The specific hematologic malignancies that benzene is associated have been outlined and they include acute myeloid leukemia, myelodysplastic syndrome, acute lymphoblastic leukemia and chronic myeloid leukemia [27].

\subsection{Benzene Formation in Beverages}

It has been previously reported [28] that the reaction of benzoic acid and ascorbic acid (vitamin C) can induce benzene formation in vitamin $C$ drinks. There is ascorbic acid inherent in fresh palm wine [29] and benzoic acid from plant material [30] can get into the drink at any point in the production process. This provides an opportunity for both compounds to combine and form benzene, which could be hazardous to health. The actual source of benzene in palm wine is still unclear and needs to be investigated further.

A survey of over 100 soft drinks and other beverage samples with a focus on soft drinks that contain both benzoate salts and ascorbic or erythorbic acid has been carried out [31] in the United States of America. It was found that four beverage products contained benzene levels above the 5 ppb quality standard for drinking water. It was also reported that these products with high benzene content were reformulated by the manufacturers, and, following a re-test, samples of these reformulated products 
showed that benzene levels were less than $1 \mathrm{ppb}$. The level of benzene in the bottled (Figure 1) and canned products is important because benzoates are likely to be used as preservatives. Corrective actions should be taken if the levels are found to be above acceptable thresholds.

\section{Trimethyldioxolane}

It is known that dioxolanes are highly flammable liquid and vapor that can easily be prepared from carbonyl compounds with 1,3-propanediol or 1,2-ethanediol in the presence of a Brönsted or a Lewis acid catalyst [32]. It is not clear if its occurrence in palm wine is through reaction between other compounds present in the palm wine or reaction between extraneous materials. However, the properties of the compound indicate that it should be avoided. The hazard warnings for the chemical states that it can cause harm if swallowed and it is suspected of causing genetic defects and damage of an unborn child [15]. Apart from one sample that was within permissible limits (Table 1), all the other samples were over the recommended IDLH limit for dioxanes. The key to reduction of this compound in the drink may be to avoid the entry of extraneous materials.

\section{Dichloro Methane}

According to Gribble et al. [33], dichloro methane or methylene chloride is among organohalogen compounds that were once dismissed as accidents of nature or isolation artifacts and natural sources include oceanic sources, macroalgae or wetlands. In addition, the majority of dichloromethane in the environment is the result of industrial emissions, and its occurrence in palm wine could be from plant material or environmental pollution. Even though the compound is reasonably implicated as a human carcinogen [34], it has many industrial uses that include insect sprays, postharvest fumigant for grains, manufacture of drugs, and decaffeination of coffee [35]. The compound can be dangerous if the lethal dose is reached as exemplified by the reported death of 14 workers who used the product to refinish bath tubs [36]. The estimated concentration levels seen in all palm wine samples analyzed is far less than the dangerous concentration limit (Table 1).

\section{Methylene Fluoride}

Methylene fluoride or difluoromethane (HFC32) is a colorless hydrofluorocarbon gas that is slightly toxic in rats [37]. It is based on methane, the most abundant hydrocarbon in the atmosphere, and it is an important greenhouse gas except that two of the four hydrogen atoms have been replaced by fluorine atoms [38]. In the YMDB [12], fluoride (YMDB 01518) is listed as a product of yeast anaerobic fermentation of Saccharomyces cerevisiae. Fluoride is a ubiquitous environmental toxin that all biological species must cope with, and protection is achieved through fluoride export proteins that protect organisms from fluoride toxicity by removing it from the cell [39]. Therefore, one way of its occurrence in palm wine may be through the reaction of methane in the atmosphere and fluoride, a product of anaerobic fermentation by yeasts.

All samples analyzed were above the IDLH limit for fluorine apart from one sample (Table 1). Environmental contamination appears to be the route of entry into palm wine. Screening the process environment for fluorides may prevent contamination. According to Tsai et al. [40], hydrofluorocarbons (HFCs) are now used as replacements for chlorofluorocarbons (CFCs) and hydrochlorofluorocarbons (HCFCs) that cause significantly stratospheric ozone depletion and global warming. In addition, they are used commercially in cleaning solvents in the electronic components, blowing agent in the foamed plastics, and refrigerant in the air conditioning units and refrigerators. It has been reported that high concentrations [41] may cause asphyxia from lack of oxygen or act as a narcotic causing central nervous system depression. The report added that overexposure can cause dizziness, headache, tiredness, nausea, unconsciousness, and cessation of breathing. 


\section{Dichloroethanol}

Dichloroethanol is regarded as a biohazard and it is flammable corrosive and harmful [15]. In rats, it is formed during the metabolism of an air borne chemical 1,2-dichloroethene by the hepatic mixed function oxidase system [42]. In this reaction, cis and trans isomers are metabolized to an epoxide and the aldehyde formed from the cis isomer yields dichloroethanol. It is also a metabolite of trichlorfon, an insecticide used to control a variety of insects on an extensive range of crops [43]. It is possible that it is an intermediate product from other reactions in the palm wine drink and not a direct contaminant. The contamination levels varied in different samples and were all within permissible limits for dichloroethane (Table 1).

\section{Dimethylhydrazine}

The estimated concentrations of dimethyl hydrazine found in all samples were far above the recommended limits (Table 1). This suggests a serious issue of environmental contamination. The compound is currently used in many cancer studies [44,45] because it is a known carcinogen that can cause sporadic forms of colon carcinoma in rats resulting in a reproducible experimental models for pre-clinical screening of test compounds based on its metabolism [46]. It has been reported that the metabolism of dimethyl hydrazine leads to the formation of azoxymethane methylazoxymethanol and methyl diazonium ions, which can cause alkylation of the DNA in the colon mucosa [47]. Dimethyl hydrazine is associated with rocket fuels, cigarette smoke, tobacco products and plant pesticides [29]. Using a theoretical approach, Carlsen et al. [48] carried out a preliminary assessment of the potential environmental and human health impact of unsymmetrical dimethylhydrazine as a result of space activities. It was revealed that inside the fall region of burned-out rocket stages constitute a significant threat to both environmental and human health, the latter as a result of the carcinogenic, mutagenic, convulsant, teratogenic and embryotoxic characteristics of dimethylhydrazine.

Apart from rocket fuel, other aforementioned substances in dimethyl hydrazine can occur in palm wine processing environment. The impact from rockets may not be a concern for now considering that Nigeria's space technology is still developing. However, smoking, use of tobacco and application of plant pesticides should be avoided in the palm wine processing environment.

\section{3-Methyl-6,7-benzylisoquinoline}

Only one sample out of the seven samples analyzed was within the recommended limit for quinone (Table 1). Avoiding extraneous leaves making contact with the drink may eliminate the problem. According to Galanie and Smolke [49], the compound benzylisoquinoline is a class 1-tyrosine derived plant alkaloids. Benzylisoquinoline alkaloids have a pharmaceutical value and they are large and structurally diverse family of plant secondary metabolites [50] that includes the opiates such as morphine [51]. Using synthetic chemistry and biology approaches, a strain of Saccharomyces cerevisiae, the dominant yeast species found in palm wine has been engineered to synthesize the key intermediate reticuline and other metabolites from benzylisoquinoline [52].

Considering that Benzylisoquinoline alkaloids are plant metabolites that are present in plant cells [53], its presence in the palm wine may be from the palm tree from which the palm wine was obtained. More knowledge may be gained if an investigation is carried out to establish if Saccharomyces cerevisiae from palm wine can naturally synthesize the compound. It has been reported that many plant species are currently recognized as toxic for both animals and humans, and some of them are known to cause their toxic effects due to their alkaloid content [54]. The report pointed out that the alkaloid content may include pyrrolizidine alkaloids and neurotoxins. Diseases associated with alkaloids from plant seeds have been reported [55] and so contact of the palm wine with plant seeds should be avoided during the palm wine production process. 


\section{Tetraacetyl-D-xylonic Nitrile}

The compound tetraacetyl-d-xylonic nitrile has been found in the ethanolic leaf extract of Croton bonplandianum [56] and has been associated with metabolism of Aspergillus niger after methanolic extracts were analyzed with gas chromatography-mass spectrometry [57]. It is also a volatile metabolite of the endophytic fungi Fusarium sp. [58] and has been listed as one of the nitrogenous products from fermented soy bean meal with Trichoderma sp. [59]. Furthermore, it has been found in trace amounts when the chemical composition of essential oils from aerial parts of Sisymbrium irio from Jordan was determined [60]. It is evident that this compound is very present in the environment and appears harmless in small amounts. However, it has been implicated in the in vitro cytotoxicity of Indian bee propolis on cancer cell lines [61]. As the compound is associated with several plants and fungal organisms, it could have entered the palm wine drink at any point in the production process. The concentration (Table 1) estimated in all of the palm wine samples is below the limit for phenols found in most plants.

\section{Physical and Other Chemical Contaminants}

Chemical contaminants in food [62] can come from pesticides and veterinary medicines used in farming, acrylamides used in processing, natural aflatoxin that occur during storage and pollutants such as dioxins in the environment. Physical and other contaminants can get into the drink through the water used for dilution. A frequent complaint by palm wine consumers is adulteration of the product with water to boost product volume followed by addition of artificial sweeteners [10]. This is why undiluted palm saps are generally more expensive than diluted ones. Due to no portable water at some palm wine processing centers in Africa, water may be sourced from nearby open wells and streams or transported with plastic containers, and, if the container has been used to store other materials, there is the possibility of introduction of extraneous materials into the drink. The extraneous items may include plant leaves, twigs and dead insects.

Ukhun et al. [63] compared the heavy metal profile of fresh palm wine and those of seven brands of bottled palm wine using atomic absorption spectroscopy in Benin City, Nigeria and found that the bottled samples contained toxic levels of either lead or cadmium. Both metals were detected in fresh palm wine and it was suggested that most of the metals detected were as a result of dilution with contaminated water. The suspicion that the water used for bottling was from questionable sources was strong, given that around the time the study was carried out, there were reports that the ground water in Benin City was reported to be contaminated with unacceptable levels of lead, cadmium, chromium and zinc [64].

\section{Toxicity Concerns with Use of Plastic Containers}

\subsection{Plastic Degradation}

Finally, there are concerns about the use of PET and other plastic containers as the main storage vessels of palm wine from the tapping process up until consumption because some of the aforementioned chemicals may be constituents of a PET or plastic container used in the production process. In Europe, European regulation No. 10/2011 [65] ensures the safety of plastic materials in contact with foodstuffs. This regulation has a list of substances that are authorized for use in plastic materials and some compounds are subject to restrictions according to their toxicological data. Such regulations can be adopted to prevent plastic hazardous material from getting into the palm wine drink.

Plastic containers are used virtually in all processing steps. Even the palm wine calabash that is popular in Nigerian folklore has been replaced by plastic containers. In a study by Obahiagbon and Oviasogie [66], the initial palm wine exudate was collected with a plastic funnel and receptacle. An investigation [67] with scanning electron microscopy and energy dispersive X-ray spectroscopy to evaluate the interactions of palm wine with the surface of its PET containers did not find any pitting or extensive corrosion. However, the PET container that was used for palm wine storage showed 
the presence of chlorine, whereas no chlorine was observed for the control sample that contained water. It was suggested that, at some point in the palm wine supply chain, a polyvinyl chloride plastic container may have been used to store the product.

Polyvinyl containers are degradable under high temperature. McNeill et al. [68] carried out a thermal degradation study and found that analysis of the liquid fraction collected during pyrolysis included hydrogen chloride, chlorine, tar, and benzene. There are other concerns that reused chemical plastic containers may still contain traces of chemicals, which may react with palm wine and cause corrosion of the plastic container. Although it is generally believed that PET bottles take a long time to degrade, the degradation of PET bottles has been successfully achieved in $2 \mathrm{~h}$ using hydrotalcite as catalyst and ethylene glycol as solvent [69]. Therefore, the various types of plastic used in the storage of the product should be evaluated to establish if there are reactions with the container.

\subsection{Other Plastic Constituents}

Bach et al. [70] carried out a comprehensive literature review which showed that contradictory results for chemical migration in PET-bottled water have been reported, and the differences can be explained by the wide variety of analytical methods, bioassays and exposure conditions employed. It was reported that analysis of PET reveals some non-intentionally added substances produced by initial reactants and additives. In addition, plasticizers, formaldehyde, acetaldehyde and antimony are related to migration from PET into bottled water, but the origin of these compounds has not been clearly established. The compounds could be from PET containers, cap-sealing resins, background contamination, water processing steps, and recycled PET bottles. The effect of sunlight exposure on chemical migration into PET-bottled waters has been studied [71]. Bottled waters were exposed to natural sunlight for 2-10 days, and it was found that migration was dependent on the type of water. PET-bottled water extracts did not induce any toxic effects, cyto-genotoxicity, estrogenic, or anti-androgenic activity in vitro at relevant consumer-exposure levels.

\section{Conclusions}

From the qualities of the chemicals outlined above, it is evident that the chemicals are potentially hazardous. It will be beneficial to public health to determine if concentrations found in palm wine are dramatically increased when compared to other food-associated samples. The concentrations of the chemical compounds in palm wine given are estimates only and a quantitative study needs to be carried out with the relevant chemical standard before the impact of these chemicals on health is evaluated. Even though private processing of the product may be difficult to monitor, unregulated commercial processing should be discouraged and only those who have been sensitized on the microbiological, physical and chemical hazards should be allowed to process and sell the product to the public. In addition, use of only food grade plastics, especially for bulk transportation of palm wine, should be allowed. Agricultural extension and health officers would need to sensitize processors to avoid reuse of plastic containers that have been used for storage of any toxic chemicals. A detailed hazard analysis that covers palm wine processing and the whole palm wine supply chain will be beneficial to public health.

Acknowledgments: The work was supported by the International Development Fund grant to O.N. from Society for General Microbiology (now Microbiology Society) UK. Grant No IDF 2012/12/3.

Author Contributions: O.N. conceived the paper; and O.N. and M.I. contributed to the paper.

Conflicts of Interest: The authors declare no conflict of interest.

\section{References}

1. Tra Bi, C.Y.; N'guessan, F.K.; Kouakou, C.A.; Jacques, N.; Casaregola, S.; Djè, M.K. Identification of yeasts isolated from raffia wine (Raphia hookeri) produced in Côte d'Ivoire and genotyping of Saccharomyces cerevisiae strains by PCR inter-delta. World J. Microbiol. Biotechnol. 2016, 32, 125. [CrossRef] [PubMed] 
2. Tapsoba, F.; Legras, J.L.; Savadogo, A.; Dequin, S.; Traore, A.S. Diversity of Saccharomyces cerevisiae strains isolated from Borassus akeassii palm wines from Burkina Faso in comparison to other African beverages. Int. J. Food Microbiol. 2015, 211, 128-133. [CrossRef] [PubMed]

3. Ouoba, L.I.; Nielsen, D.S.; Anyogu, A.; Kando, C.; Diawara, B.; Jespersen, L.; Sutherland, J.P. Hanseniaspora jakobsenii sp. nov., a yeast isolated from Bandji, a traditional palm wine of Borassus akeassii. Int. J. Syst. Evol. Microbiol. 2015, 65, 3576-3579. [CrossRef] [PubMed]

4. Canadian Food Inspection Agency. Food Safety Hazards. Available online: http://www.inspection. gc.ca/food/non-federally-registered/product-inspection/inspection-manual/eng/1393949957029/ 1393950086417?chap $=5$ (accessed on 14 November 2016).

5. Mbuagbaw, L.; Noorduyn, S. The palm wine trade: Occupational and health hazards. Int. J. Occup. Environ. Med. 2012, 3, 157-164. [PubMed]

6. Food Standards Agency, United Kingdom. Hazard Analysis and Critical Control Points. Available online: https:/ / www.food.gov.uk/business-industry/food-hygiene/haccp (accessed on 16 November 2016).

7. Karamoko, D.; Djeni, N.T.; N'Guessan, K.F.; Bouatenin, K.M.J.P.; Dje, K.M. The biochemical and microbiological quality of palm wine samples produced at different periods during tapping and changes which occurred during their storage. Food Control 2012, 26, 504-511. [CrossRef]

8. Karamoko, D.; Deni, N.T.; Moroh, J.L.A.; Bouatenin, K.M.J.P.; Dje, K.M. Biochemical and microbial properties of palm wine: Effect of tapping length and varietal differences. Food Nutr. Sci. 2016, 7, 763-771. [CrossRef]

9. Tapsoba, F.; Savadogo, A.; Legras, J.L.; Zongo, C.; Traore, A.S. Microbial diversity and biochemical characteristics of Borassus akeassii wine. Lett. Appl. Microbiol. 2016, 63, 297-306. [CrossRef] [PubMed]

10. Iwegbue, C.M.; Ojelum, A.L.; Bassey, F.I. A Survey of metal profiles in some traditional alcoholic beverages in Nigeria. Food Sci. Nutr. 2014, 2, 724-733. [CrossRef] [PubMed]

11. Nwaiwu, O.; Ibekwe, V.I.; Amadi, E.S.; Udebuani, A.C.; Nwanebu, F.C.; Oguoma, O.I.; Nnokwe, J.C. Evaluation of fermentation products of palm wine yeasts and role of Sacoglottis gabonensis supplement on products abundance. Beverages 2016, 2, 1-13. [CrossRef]

12. Jewison, T.; Knox, C.; Neveu, V.; Djoumbou, Y.; Guo, A.C.; Lee, J.; Liu, P.; Mandal, R.; Krishnamurthy, R.; Sinelnikov, I.; et al. YMDB: The Yeast Metabolome Database. Nucleic. Acids Res. 2012, 40, D815-D820. [CrossRef] [PubMed]

13. Uzochukwu, S.V.A.; Balogh, E.; Tucknott, O.; Lewis, M.J.; Ngoddy, P.O. Volatile constituents of palm wine and palm sap. J. Sci. Food Agric. 1994, 64, 405-411. [CrossRef]

14. Lasekan, O.; Otto, S. In vivo analysis of palm wine (Elaeis guineensis) volatile organic compounds (VOCs) by proton transfer reaction-mass spectrometry. Int. J. Mass Spectrom. 2009, 282, 45-49. [CrossRef]

15. PubChem. The PubChem Project. Available online: https://pubchem.ncbi.nlm.nih.gov/ (accessed on 13 September 2016).

16. Center for Disease Control and Prevention, United States of America. Chemical Listing and Documentation of Revised IDLH Values. Available online: https://www.cdc.gov/niosh/idlh/intridl4.html (accessed on 20 January 2017).

17. USDE. New Process for Producing Styrene Cuts Costs, Saves Energy, and Reduces Greenhouse Gas Emissions. Available online: http://www1.eere.energy.gov/office_eere/pdfs/exelus_case_study.pdf (accessed on 15 November 2016).

18. Nakaia, M.; Tsubokuraa, M.; Suzukia, M.; Fujishimaa, S.; Watanabeb, Y.; Hasegawab, Y.; Oyamab, K.; Shozo, O. Genotoxicity of styrene oligomers extracted from polystyrene intended for use in contact with food. Toxicol. Rep. 2014, 1, 1175-1180. [CrossRef]

19. Arochena, L.; Fernández-Nieto, M.; Aguado, E.; García del Potro, M.; Sastre, J. Eosinophilic bronchitis caused by styrene. J. Investig. Allergol. Clin. Immunol. 2014, 24, 68-69. [PubMed]

20. Fischer, C.S.; Bayer, O.; Strupp, M. Transient bilateral vestibular dysfunction caused by intoxication with low doses of styrene. Eur. Arch. Otorhinolaryngol. 2014, 271, 619-623. [CrossRef] [PubMed]

21. Johnson, A.C. Relationship between styrene exposure and hearing loss: Review of human studies. Int. J. Occup. Med. Environ. Health 2007, 20, 315-325. [CrossRef] [PubMed]

22. Campo, P.; Maguin, K. Solvent-induced hearing loss: Mechanisms and prevention strategy. Int. J. Occup. Med. Environ. Health 2007, 20, 265-270. [CrossRef] [PubMed] 
23. Seeber, A.; Blaszkewicz, M.; Golka, K.; Hallier, E.; Kiesswetter, E.; Schäper, M.; van Thriel, C. Neurobehavioral effects of experimental exposures to low levels of styrene. Toxicol. Lett. 2004, 151, 183-192. [CrossRef] [PubMed]

24. Benignus, V.A.; Geller, A.M.; Boyes, W.K.; Bushnell, P.J. Human neurobehavioral effects of long-term exposure to styrene: A meta-analysis. Environ. Health Perspect. 2005, 113, 532-538. [CrossRef] [PubMed]

25. Vodicka, P.; Tuimala, J.; Stetina, R.; Kumar, R.; Manini, P.; Naccarati, A.; Maestri, L.; Vodickova, L.; Kuricova, M.; Järventaus, H.; et al. Cytogenetic markers, DNA single-strand breaks, urinary metabolites, and DNA repair rates in styrene-exposed lamination workers. Environ. Health Perspect. 2004, 112, 867-871. [CrossRef] [PubMed]

26. United States Environmental Protection Agency. Assessing Outdoor Air near Schools-Monitored Pollutants. Available online: https: / www3.epa.gov/air/sat/pollutants.html (5 January 2016).

27. Smith, M.T. Advances in understanding benzene health effects and susceptibility. Annu. Rev. Publ. Health 2010, 3, 133-148. [CrossRef] [PubMed]

28. Ju, H.K.; Park, J.H.; Kwon, S.W. Evaluation of headspace-gas chromatography/mass spectrometry for the analysis of benzene in vitamin C drinks; pitfalls of headspace in benzene detection. Biomed. Chromatogr. 2008, 22, 900-905. [CrossRef] [PubMed]

29. Okwu, D.E.; Nnamdi, F.U. Evaluation of the chemical composition of Dacryodes edulis and Raphia hookeri Mann and Wendl exudates used in herbal medicine in south eastern Nigeria. Afr. J. Tradit. Complement. Altern. Med. 2008, 5, 194-200. [CrossRef] [PubMed]

30. NTP - National Toxicology Program. Report on Carcinogens, 13th ed.Department of Health and Human Services, Public Health Service: Research Triangle Park, NC, USA, 2014. Available online: http:/ /ntp.niehs. nih.gov/pubhealth/roc/roc13/ (accessed on 17 November 2016).

31. Food and Drug Administration. Data on Benzene in Soft Drinks and Other Beverages. Available online: https: //www.fda.gov/Food/FoodborneIllnessContaminants/ChemicalContaminants/ucm055815.htm (accessed on 11 November 2016).

32. Green, T.W.; Wuts, P.G.M. Protective Groups in Organic Synthesis; Wiley-Interscience: New York, NY, USA, 1999; pp. 308-322.

33. Gribble, G.W. Naturally Occurring Organohalogen Compounds-A Comprehensive Update; Springer: New York, NY, USA, 2010; pp. 9-348.

34. Liu, T.; Xu, Q.E.; Zhang, C.H.; Zhang, P. Occupational exposure to methylene chloride and risk of cancer: A meta-analysis. Cancer Causes Control 2013, 24, 2037-2049. [CrossRef] [PubMed]

35. Methylene Chloride; Natural Resources Defense Council: New York, NY, USA, 2010; Available online: https: //www.nrdc.org/sites/default/files/methyleneChloride.pdf (accessed on 11 November 2016).

36. Hall, R.M. Dangers of Bathtub Refinishing; Center for Disease Control: Atlanta, GA, USA, 2013. Available online: http://blogs.cdc.gov/niosh-science-blog/2013/02/04/bathtub-refinishing/ (accessed on 11 November 2016).

37. Ema, M.; Naya, M.; Yoshida, K.; Nagaosa, R. Reproductive and developmental toxicity of hydrofluorocarbons used as refrigerants. Reprod. Toxicol. 2010, 29, 125-131. [CrossRef] [PubMed]

38. Brzezińska, M.; Nosalewicz, M.; Pasztelan, M.; Włodarczyk, T. Methane production and consumption in loess soil at different slope position. Sci. World J. 2012, 2012, 1-8.

39. Smith, K.D.; Gordon, P.B.; Rivetta, A.; Allen, K.E.; Berbasova, T.; Slayman, C.; Strobel, S.A. Yeast Fex1p is a constitutively expressed fluoride channel with functional asymmetry of its two homologous domains. J. Biol. Chem. 2015, 290, 19874-19887. [CrossRef] [PubMed]

40. Tsai, W.T. An overview of environmental hazards and exposure risk of hydrofluorocarbons (HFCs). Chemosphere 2005, 61, 1539-1547. [CrossRef] [PubMed]

41. Difluoromethane. CAS No. 75-10-5. Chemical Book. CAS Database List. Available online: http://www. chemicalbook.com/ChemicalProductProperty_EN_cb6175830.html (accessed on 11 November 2016).

42. National Research Council, USA. Accute Exposure Guidelines for Selected Airborne Chemicals; National Academies Press: Washington, DC, USA, 2010; Volume 8, pp. 144-185.

43. A Insecticide and Acaricide Used to Control a Variety of Insects on An Extensive Range of Crops. Available online: http:/ / sitem.herts.ac.uk/aeru/iupac/Reports/657.htm (assessed on 31 October 2016). 
44. Tawfik, M.K.; Mohamed, M.I. Exenatide suppresses 1,2-dimethylhydrazine-induced colon cancer in diabetic mice: Effect on tumor angiogenesis and cell proliferation. Biomed. Pharmacother. 2016, 82, 106-116. [CrossRef] [PubMed]

45. Malayeri, M.R.; Dadkhah, A.; Fatemi, F.; Dini, S.; Torabi, F.; Tavajjoh, M.M.; Rabiei, J. Chemotherapeutic effect of Berberis integerrima hydroalcoholic extract on colon cancer development in the 1,2-dimethyl hydrazine rat model. Z. Naturforsch. C 2016, 71, 225-232. [CrossRef] [PubMed]

46. Prasad, V.G.; Reddy, N.; Francis, A.; Nayak, P.G.; Kishore, A.; Nandakumar, K.; Rao, M.C.; Shenoy, R. Sambar, an Indian dish prevents the development of dimethyl hydrazine-induced colon cancer: A preclinical study. Pharmacogn. Mag. 2016, 12, S441-S445. [PubMed]

47. Fiala, E.S. Investigations into the metabolism and mode of action of the colon carcinogens 1,2-dimethyl hydrazine and azoxymethane. Cancer 1977, 40, 2436-2445. [CrossRef]

48. Carlsen, L.; Kenesova, O.A.; Batyrbekova, S.E. A preliminary assessment of the potential environmental and human health impact of unsymmetrical dimethylhydrazine as a result of space activities. Chemosphere 2007, 67, 1108-1116. [CrossRef] [PubMed]

49. Galanie, S.; Smolke, C.D. Optimization of yeast-based production of medicinal protoberberine alkaloids. Microb. Cell. Fact. 2015, 14, 1-13. [CrossRef] [PubMed]

50. Hawkins, K.M.; Smolke, C.D. Production of benzylisoquinoline alkaloids in Saccharomyces cerevisiae. Nat. Chem. Biol. 2008, 4, 564-573. [CrossRef] [PubMed]

51. Morais, L.C.; Barbosa-Filho, J.M.; Almeida, R.N. Central depressant effects of reticuline extracted from Ocotea duckei in rats and mice. J. Ethnopharmacol. 1998, 62, 57-61. [CrossRef]

52. Narcross, L.; Fossati, E.; Bourgeois, L.; Dueber, J.E.; Martin, V.J. Microbial factories for the production of benzylisoquinoline alkaloids. Trends Biotechnol. 2016, 34, 228-241. [CrossRef] [PubMed]

53. Minami, H. Fermentative production of plant benzylisoquinoline alkaloids in microbes. Biosci. Biotechnol. Biochem. 2013, 77, 1617-1622. [CrossRef] [PubMed]

54. Diaz, G.J. Toxicosis by plant alkaloids in humans and animals in Colombia. Toxins (Basel) 2015, 7, 5408-5416. [CrossRef] [PubMed]

55. Diaz, G.J.; Roldán, L.P.; Cortés, A. Intoxication of Crotalaria pallida seeds to growing broiler chicks. Vet. Hum. Toxicol. 2003, 45, 187-189. [PubMed]

56. Keerthana, G.; Kalaivani, M.K.; Sumathy, A. In Vitro alpha amylase inhibitory and anti-oxidant activities of ethanolic leaf extract of Croton bonplandianum. Asian J. Pharm. Clin. Res. 2013, 6, 32-36.

57. Hameed, I.H.; Hamza, L.F.; Sabreen, A. Kamal Analysis of bioactive chemical compounds of Aspergillus niger by using gas chromatography-mass spectrometry and Fourier-transform infrared spectroscopy. J. Pharmacogn. Phytother. 2015, 7, 132-163.

58. Toghueo, K.R.M.; Dinkar, S.; Fekam, B.F. Impact of small chemical elicitors on the production of volatile metabolites by endophytic fungi Fusarium sp. and Phomopsis sp. from Cameroonian medicinal plants. Sch. Acad. J. Pharm. 2016, 5, 371-376.

59. Ramadan, M.M.; Elbandy, M.A.; Fadel, M.; Ghanem, K.Z. Biotechnological production of volatile and non-volatile antioxidant compounds from fermented soy bean meal with Trichoderma sp. Res. J. Pharm. Biol. Chem. Sci. 2014, 5, 537-547.

60. Al-qudah, M.A.; Abu zarga, M.H. Chemical composition of essential oils from aerial parts of Sisymbrium irio from Jordan. E-J. Chem. 2010, 7, 6-10. [CrossRef]

61. Shubharani, R.; Sivaram, V.; Kishore, B.R. In Vitro cytotoxicity of Indian bee propolis on cancer cell lines. Int. J. Pharm. Biol. Sci. 2014, 5, 698-706.

62. Food Standard Agency. United Kingdom. Guidance notes, Importing Food Containing Contaminants. Available online: https://www.food.gov.uk/business-industry/imports/importers/contaminant (accessed on 20 January 2016).

63. Ukhun, M.E.; Okolie, N.P.; Onyerinde, A.O. Some mineral profile of fresh and bottled palm wine-A comparative study. Afr. J. Biotechnol. 2005, 4, 829-832.

64. Erah, P.O.; Akujieze, C.N.; Oteze, G.E. The quality of ground water in Benin City: A baseline study on inorganic chemicals and microbial contaminants of health importance in boreholes and open wells. Trop. J. Pharm. Res. 2002, 1, 75-82. [CrossRef] 
65. European commission. Union Guidance on Regulation (EU) No 10/2011 on Plastic Materials and Articles Intended to Come into Contact with Food as Regards Information in the Supply Chain. Available online: https:/ / ec.europa.eu/food/sites/food/files/safety/docs/cs_fcm_plastic-guidance_201110_reg_ en.pdf (accessed on 2 October 2016).

66. Obahiagbon, F.I.; Oviasogie, P. Changes in the physicochemical characteristics of processed and stored Raphia hookeri palm sap (shelf life studies). Am. J. Food Technol. 2007, 2, 323-326.

67. Osarolube, E.; Nwaiwu, O. Probing yeast fermented palm wine interactions with the surface of its plastic container. Arch. Appl. Sci. Res. 2016, 8, 77-84.

68. McNeill, I.C.; Memetea, L.; Cole, J.C. A study of the products of PVC thermal degradation. Polym. Degrad. Stab. 1995, 49, 181-191. [CrossRef]

69. Sharma, V.; Shrivastava, P.; Agarwal, D.D. Degradation of PET-bottles to monohydroxyethyl terephthalate (MHT) using ethylene glycol and hydrotalcite. J. Polym. Res. 2015, 22, 241. [CrossRef]

70. Bach, C.; Dauchy, X.; Chagnon, M.C.; Etienne, S. Chemical compounds and toxicological assessments of drinking water stored in polyethylene terephthalate (PET) bottles: A source of controversy reviewed. Water Res. 2012, 46, 571-583. [CrossRef] [PubMed]

71. Bach, C.; Dauchy, X.; Severin, I.; Munoz, J.F.; Etienne, S.; Chagnon, M.C. Effect of sunlight exposure on the release of intentionally and/or non-intentionally added substances from polyethylene terephthalate (PET) bottles into water: Chemical analysis and in vitro toxicity. Food Chem. 2014, 162, 63-71. [CrossRef] [PubMed]

(c) 2017 by the authors. Licensee MDPI, Basel, Switzerland. This article is an open access article distributed under the terms and conditions of the Creative Commons Attribution (CC BY) license (http:/ / creativecommons.org/licenses/by/4.0/). 